\title{
American cigarette manufacturers' ability to pay damages: overview and a rough calculation
}

\author{
Jeffrey E Harris
}

\begin{abstract}
The American cigarette industry's ability to pay large damage awards and settlement costs is not limited to its current annual profits of $\$ 7.6$ billion, or \$0.31 per pack. Much larger liability payments could be financed through increased wholesale cigarette prices or higher excise taxes. An increase in the federal cigarette excise tax of 50 cents per pack could yield an estimated $\$ 10.8$ billion annually in net revenues available for liability costs, while the industry would still retain $\$ 5.4$ billion, or $\$ 0.25$ per pack, in pre-tax profits.

An increase in cigarette price from its current $\$ 1.88$ per pack to the full, monopoly profit-maximising level of $\$ 4.08$ per pack would make more than $\$ 32$ billion available annually for liability payments or pre-taxed profits.
\end{abstract}

(Tobacco Control 1996;5:292-294)

\section{Introduction}

As an increasing number of state and local governments file suit against American cigarette manufacturers, and as more courts set trial dates for class-action suits on behalf of smokers, the possibility looms larger that tobacco companies may be required to pay out large sums to comply with court-imposed damage awards, to reach private out-of-court settlements, or to buy some sort of immunity sanctioned by the US Congress.

In early 1996, the Liggett Group, a relatively small company with a $2 \%$ American market share, reportedly settled with the Castano class-action plaintiffs and some state attorneys general for combined amounts exceeding $\$ 2$ million annually (about $20 \%$ of current pre-tax income) for 25 years. ${ }^{1}$ By August, rumours had surfaced of a legislative proposal whereby the industry would contribute to a super-fund for 15 years - in annual payments escalating from $\$ 6$ billion in 1997 to $\$ 10$ billion in 2001 and thereafter-in return for immunity from future liability suits, a cap on possible damages from pending actions, and a reprieve from regulation by the Food and Drug Administration. ${ }^{2}$

These recent developments pose a larger question.

\section{How much can American cigarette makers pay?}

In 1995 , American smokers spent $\$ 45.8$ billion to consume 24.35 billion packs of cigarettes. ${ }^{3}+$ Of the $\$ 45.8$ billion spent on cigarettes approximately $\$ 13.0$ billion went toward payment of excise taxes levied by federal, state and local governments ${ }^{3} ; \$ 12.7$ billion went to retailers and wholesalers; and $\$ 20.1$ billion went to cigarette manufacturing companies. $\frac{\text { D }}{3}$ Of the $\$ 20.1$ billion in manufacturers' receipts, an estimated $\$ 7.6$ billion was reported as oper- ating profit, ${ }^{4}$ whereas the remaining $\$ 12.5$ bil-e lion went for cigarette production and market-oึ ing, including the costs of tobacco leaf.

Thus, in 1995, Americans paid an average of $\$ 1.88$ for each pack of cigarettes, of which $53 \frac{\mathrm{O}}{\mathrm{O}}$ cents went to excise taxes; 52 cents went tof retailers and wholesalers; and 83 cents went to cigarette manufacturers. Of the 83 cents per pack received by manufacturers, about 313 cents were reported as operating profit.

In some discussions, the current industry wide total of $\$ 7.6$ billion in annual operating profits is taken to be a practical upper limit on the cigarette industry's ability to pay damages and settlement costs arising from productson liability and related litigation. Such a position is unwarranted, however, because it incorrectlyō assumes that cigarette manufacturers will noto or cannot raise cigarette prices to finance dam age payments.

\section{Industry's ability to pay damages}

In reality, the industry's ability to pay damages is bounded by the maximum amount of money it could extract from smokers if the price of cigarettes were set at its full, monopoly profit-maximising level. A rough calculation N given in the appendix below-suggests that the $e_{\sigma}^{\omega}$ monopoly profit-maximising price of cigarettes in the United States is currently about $\$ 4$ per: pack. At such a price, annual pre-tax profits would exceed $\$ 32$ billion annually.

The requisite increase in retail cigaretteo price can be achieved either by governmental ${ }_{0}^{\mathbb{D}}$ excise-tax levies or by manufacturers via wholesale price revisions. In view of the facto that the American cigarette industry is an five-firm oligopoly, however, it would beo administratively and legally simpler for a⿳亠二口犬 governmental authority to raise cigarette taxes? and earmark the proceeds for a liability settlement. Consider, for example, a settlement sanctioned by government in which Congress 
raised the federal excise tax by 50 cents to the point where cigarettes retailed for about $\$ 2.38$ per pack-well below the full monopoly price-and manufacturers were permitted to retain an operating margin of 25 cents per pack. As detailed in the appendix, such a scheme would create a fund of about $\$ 10.8$ billion annually in new governmental tax revenues - an amount exceeding the industrywide mega-payments proposed last summerwhile manufacturers would still earn about $\$ 5.4$ billion in pre-tax profits. Based on current estimates of the "litigation discount" in cigarette-makers' stock prices, ${ }^{5}$ manufacturers and their shareholders would quite likely accept a cut in profits of $\$ 2.2$ billion in return for dissolving the cloud of liability that currently hangs over the industry.

In contrast with a price increase authorised by government, manufacturers could raise prices on their own. In that case, a price increase of $\$ 0.50$ per pack would require manufacturers to raise their wholesale cigarette prices in concert by about $60 \%$. In view of the high barriers to entry and extremely high concentration of market power in the cigarette industry, ${ }^{6}$ a coordinated price increase of this magnitude is hardly infeasible, but it is not without antitrust problems. The task of coordinating price increases to finance liability payments would be even more complicated if a settlement were reached or damages were imposed on only one manufacturer. For example, if a large manufacturer such as Philip Morris (currently with $46 \%$ of American sales) were subject to a separate judgment, then its ability to finance damage payments through price increases could hinge on the propensity of RJ Reynolds (26\% market share), Brown \& Williamson (18\% share), and other smaller firms to raise their prices in tandem.

As noted in the appendix, my calculations require specific assumptions about the shape of the demand curve for cigarettes. Since my

\section{Appendix \\ Calculation of the full, monopoly profit-maximising price of cigarettes}

Let $p$ denote the average retail price of cigarettes; $q$, the number of packs consumed annually; and $c$, the unit cost of a pack of cigarettes. To keep the analysis manageable, I assume that unit cost $c$ per pack of cigarettes does not depend on the quantity $q$ that is produced and sold. Thus, the amount $(p-c)$ represents the profit per pack of cigarettes. In 1995 , we have: $p_{0}=\$ 1.88$ per pack; $q_{0}=24.35$ billion packs; $\left(p_{0}-c\right)=\$ 0.31$ per pack; and $c=\$ 1.57$ per pack (where the subscript " 0 " refers to specifically to 1995 values). By this method of accounting, the unit cost $c$ includes not only manufacturers' cost of production, but also excise tax payments to governments and the amount that retailers and wholesalers keep for themselves. assumptions may be in error, the calculations have to be taken as rough estimetes. Still, my results support the conclusion that the American cigarette industry's ability to ity damages far exceeds the $\$ .6$ billion in operating profits that it currently earns.

Consumers' demand for cigare ites is considered by economists to be insengitive to price increases. That means the industof can pass on a very large fraction of its potentigi damage and settlement costs to consumers. बू. shareholders and managemento of cigarette companies might incur substantial losses, the fact is that most of the money will ultimately come from those people who $\vec{\omega}$ continue to smoke.

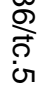

Critiques by the editor and an anonymous referee are gratefully acknowledged. The author is solely responsible for the opinions expressed here.
음

1 Glass C. No to Lebow: RJR Nabisco strareholders reject immediate spinoff. Tobacco Reporter 1996 123(5):26,28

2 Freedman A, Hwang S, Lipin S, Geye ${ }_{3}$ M. Legislation plan on tobacco advances: cigarette firnowould get immunity for 15 years from liability lawsuits. JWall Street fournal 1996 Aug 26:A2.

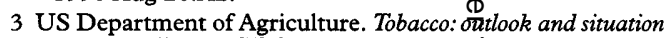
report April 1996;TBS-234:tables 1,33,30.

4 Black GD, Rooney JF. Should the tobaccosprdustry settle? The value of peace. Bernstein Research, 30 A Ig 1996: Exhibit 2.

5 France M. Big Tobacco may be ready to deal. Business Week 1996 Oct 7: 150,152 (citing estimates Rom Smith Barney and Salomon Bros).

6 Harris JE. The 1983 increase in the feral excise tax on cigarettes. In: Summers L, ed. Tax polig and the economy, vol 1. Cambridge, Massachusetts: MIT $987: 87-111$.

7 Harris JE. $A$ working model for predicting consumption and revenue impacts of large increases in the $\$ 5$ Federal cigarette excise tax. Working Paper No 4803. Combridge, Massachusetts: National Bureau of Economic Research, Jul 1994.

8 Sweanor D, Ballin S, Corcoran RD, etcal. Report of the Tobacco Policy Research Study Group on tobacco pricing and taxation in the United States Tobacco Control 1992;1(Suppl): S31-6.

9 Becker GS, Grossman M, Murphy R̂̉. An empirical analysis of cigarette addiction. Am ZEcon Rev 1994; 84(3):396-418.

10 US Centers for Disease Control and Prêgention. Cigarette smoking before and after an excise tax increase and anti-smoking campaign-Massachusetrs, 1990-1996. MMWR 1996;45:966-70
To further simplify the calculation, I assume a linear demand curve. That is, tife relationship between the retail price $p$ and quantity consumed $q$ is governed by $\operatorname{Re}$ equation: $p=A-B q$, where $A$ and $B$ are positive numbers. For a linear demand cưfve, the price elasticity of demand (that is, thercentage drop in consumption resulting ffom a $1 \%$ rise in price) is given by the formula:꿍

$$
E=p /(B q) \text {. }
$$

I assume that, in 1995, the priat elasticity $E_{0}$ was equal to $0.4 .^{6-8}$ From the values of $p_{0}, q_{0}$, and $E_{0}$ in 1995, I compute that, for the linear demand curve, $A=6.58$ and $B=0.193$.

For a linear demand curve With constant unit costs, it is a well known result in microeconomics that the full monopoly profitmaximising price is given by the formula:

$$
1 / 2(A+c),
$$


which comes to a retail price of $\$ 4.08$ per pack. At that price, the maximum profit would be given by the formula:

$1 / 4(A-c)^{2} / B$

which amounts to $\$ 32.5$ billion annually. At the full monopoly price, total cigarette consumption would be reduced from its current level to $1 / 2(A-c) / B$, which equals 13.0 billion packs annually.

This simple linear model can be used to compute the impact of a price increase of any other magnitude. As discussed above, if the federal excise tax were raised to the point where the retail price were $p_{1}=\$ 2.38$ per pack, then the quantity demanded would be $q_{1}=\left(A-p_{1}\right) / B$, which comes to 21.76 billion packs annually. Gross tax proceeds would equal $\left(p_{1}-c\right) q_{1}$, which amounts to $\$ 17.63$ billion. Annual cigarette consumption would decrease by $q_{0}-q_{1}=2.59$ billion packs. With current governmental taxes equal to $t=\$ 0.53$ per pack, the gross proceeds would be offset by a tax loss equal to $t\left(q_{0}-q_{1}\right)$, or $\$ 1.37$ billion. That leaves a net increase of $\$ 16.26$ billion in excise tax revenues. If manufacturers were permitted to retain an operating margin of $\$ 0.25$ per pack, their profits would equal $0.25 q_{1}$, which comes to $\$ 5.44$ billion. Net tax proceeds available for liability payments would therefore equal $\$ 10.82$ billion annually. Some observers may object that the reduction in cigarettedemand of 2.59 billion packs will mean los wages and income taxes. Because Americang cigarette manufacturers are diversified, multi $\frac{2}{0}$ national, consumer-product firms, I believe it:is fair to assume that the assets currently $\overrightarrow{\bar{c}_{\text {. }}}$ employed to produce and sell those 2.59 billiono packs of cigarettes could be productivelyo re-allocated elsewhere.

One group of economists claims to have measured a long-run price elasticity of demandw for cigarettes as high as 0.8 , based solely uponpre-1985 data on states' tax receipts. ${ }^{9}$ Such an extreme finding has thus far not been $\vec{w}$ replicated, and may not apply to the post-1985 period. ${ }^{7}{ }^{10}$ Even if the long-run price elasticityer of demand were as high as 0.8 , the linear modeit would nonetheless yield a monopoly profit of $\$ 18$ billion annually.

More complex models designed to predict? the impact of large price increases are currently under development. ${ }^{7}$ Although the linearo model is simple to manipulate and may be rea- $-\frac{\mathbb{Z}}{3}$ sonably accurate for small increments in price it appears to overstate the impact of large price increases on cigarette use and thus to underes- -6 timate to maximum monopoly profit attainable in the American cigarette market.

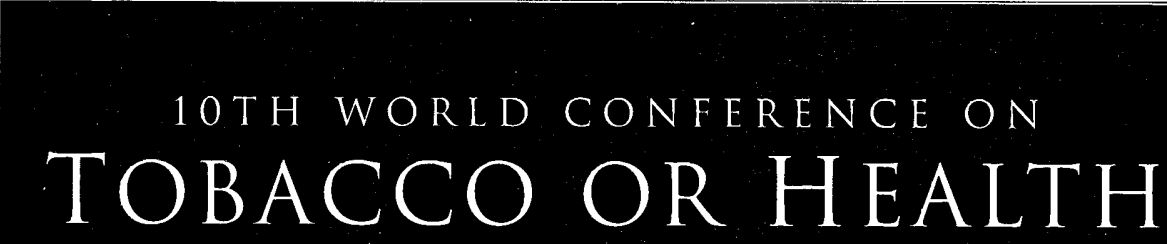

Beijing, 24-28 August 1997

The conference will be a world-wide forum to share the latest scientific advances in the whole field of tobacco issues, which include health effects of: - smoking - passive smoking - smokeless tobacco use - health promotion - tobacco legisfation - smoking cessation as well as: - tobacco smuggling - tobacco marketing - tobacco advertising - economics - taxation etc - tobacco control adrocacy
Venue: Beijing International Convention Centre For more information contact: Secretariat, 10th WCTOH, Chinese Association on Smoking \& Healtifi, Building 12, Dist. I, Anhuaxili, Beijing 10 0011, CHINA, Telephone/Fax: $(84$ 10) 4260978

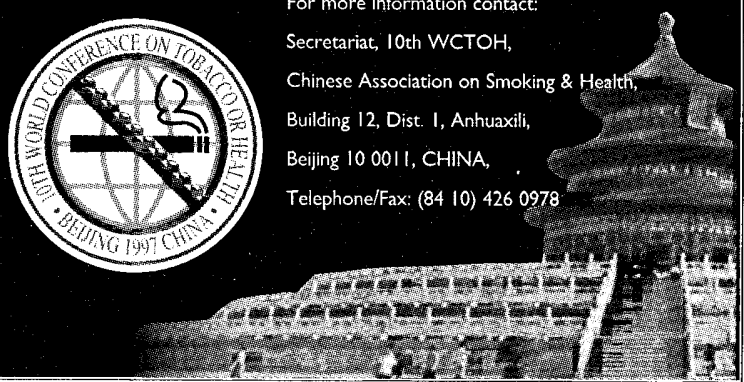

